\title{
Screening of antibacterial extracts from plants native to the Brazilian Amazon Rain Forest and Atlantic Forest
}

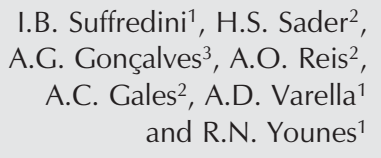

I.B. Suffredini ${ }^{1}$, H.S. Sader ${ }^{2}$, A.G. Gonçalves ${ }^{3}$, A.O. Reis ${ }^{2}$,

A.C. Gales ${ }^{2}$, A.D. Varella ${ }^{1}$ and R.N. Younes ${ }^{1}$

\author{
'Laboratório de Extração, Universidade Paulista, São Paulo, SP, Brasil \\ ${ }^{2}$ Laboratório Especial de Microbiologia Clínica, Universidade Federal de São Paulo, \\ São Paulo, SP, Brasil \\ ${ }^{3}$ Centro de Ciências Biológicas e da Saúde, Universidade Federal do Maranhão, \\ São Luís, MA, Brasil
}

\begin{abstract}
Correspondence
I.B. Suffredini

Laboratório de Extração

Universidade Paulista

Av. Paulista, 900, 1ํandar 01310-100 São Paulo, SP

Fax: +55-11-3170-3978

E-mail: extractlab@unip.br

Presented at the XXI Congresso Brasileiro de Microbiologia, Foz do Iguaçu, PR, Brasil,

October 21, 2001.

Research supported by FAPESP (No. 99/05904-6).
\end{abstract}

Received May 24, 2002 Accepted October 20, 2003

\begin{abstract}
More than $20 \%$ of the world's biodiversity is located in Brazilian forests and only a few plant extracts have been evaluated for potential antibacterial activity. In the present study, 705 organic and aqueous extracts of plants obtained from different Amazon Rain Forest and Atlantic Forest plants were screened for antibacterial activity at 100 $\mu \mathrm{g} / \mathrm{ml}$, using a microdilution broth assay against Staphylococcus aureus, Enterococcus faecalis, Pseudomonas aeruginosa and Escherichia coli. One extract, VO581, was active against $S$. aureus (minimum inhibitory concentration (MIC) $=140 \mu \mathrm{g} / \mathrm{ml}$ and minimal bactericidal concentration $(\mathrm{MBC})=160 \mu \mathrm{g} / \mathrm{ml}$, organic extract obtained from stems) and two extracts were active against $E$. faecalis, SM053 $(\mathrm{MIC}=80 \mu \mathrm{g} / \mathrm{ml}$ and $\mathrm{MBC}=90 \mu \mathrm{g} / \mathrm{ml}$, organic extract obtained from aerial parts), and MY841 (MIC $=30 \mu \mathrm{g} / \mathrm{ml}$ and $\mathrm{MBC}=50 \mu \mathrm{g} / \mathrm{ml}$, organic extract obtained from stems). The most active fractions are being fractionated to identify their active substances. Higher concentrations of other extracts are currently being evaluated against the same microorganisms.
\end{abstract}

Key words

- Plant extract

- Antibacterial activity

- Screening

- Amazon Rain Forest

- Atlantic Forest

..........................

\section{Introduction}

The Brazilian Amazon Rain Forest is home to $17 \%$ of the biodiversity found within the country (1). The Atlantic Forest contains approximately $35 \%$ of the world's Angiospermae, and more than $8 \%$ of the Pteridophytae (2). In view of this wealth of species and that the Atlantic Forest is one of the world's foci for conservation (3), this biomas should be studied in terms of pharmacological or biological activity.

Approximately $20 \%$ of the plants found in the world have been submitted to pharmacological or biological test, and a substantial number of new antibiotics introduced on the market are obtained from natural or semisynthetic resources. It has been reported that between the years 1983 and 1994, of 93 new antibacterial agents submitted to analysis by the FDA six were natural products (teicoplanin, mupirocin, miokamycin, carumonam, isepamicin, and RV-11), 45 were semisynthetic products modeled on a natural product lead, and 7 antivirals were synthetic compounds based on natural product models (4). The systematic screening of antibacterial plant extracts represents a continuous effort to find new compounds with the potential to act against multi-resistant bacteria. 
The principal aim of the present study was to screen organic and aqueous extracts obtained from the Brazilian Amazon Rain Forest and Atlantic Forest for antibacterial activity against Staphylococcus aureus, Enterococcus faecalis, Pseudomonas aeruginosa, and Escherichia coli.

\section{Material and Methods}

\section{Plant collection and extract preparation}

All plants were collected with the authorization of Instituto Brasileiro do Meio Ambiente e dos Recursos Naturais Renováveis (IBAMA), permits No. 053/99 and 038/ 99. Plants were identified by Dr. Alexandre A. Oliveira, USP, Ribeirão Preto, SP, Brazil, and vouchers are deposited at the Herbarium UNIP (Universidade Paulista, São Paulo, SP, Brazil).

Seven hundred and five organic and aqueous extracts were obtained from plants native to the Amazon Rain Forest and Atlantic Forest. Plants were collected using a traditional (5) and chemosystematic (6) approach. Plant parts were collected according to the biomass availability of each individual or population, which varied according to the species and habitat of each one, i.e., trees, herbaceous plants, lianas, epiphytes or shrubs. Plant material was dried and ground before being submitted to 24-h maceration with methanol:dichloromethane (1:1) followed by 24 -h maceration with water, resulting in two extracts from each plant material. Further information on the technique can be found elsewhere (7). The number of extracts of each family tested is given in the current text.

\section{Antimicrobial assay}

Broth microdilution method was used to screen the 705 plant extracts. The inoculum was prepared at the concentration of $10^{-2}$ $\mathrm{CFU} / \mathrm{ml}$, starting from a $0.5 \mathrm{McFarland}$ (or $10^{8} \mathrm{CFU} / \mathrm{ml}$ ) prepared from fresh colonies of bacteria as described below (8).

S. aureus ATCC 29213 (Sau), E. coli ATCC 25922 (Ecol), E. faecalis ATCC 29212 (Efae) and P. aeruginosa ATCC 27853 (Psa) were the bacterial strains tested. The bacterial inoculum of each ATCC strain was obtained from fresh colonies grown on Müeller Hinton agar plates. Each strain was inoculated into $5 \mathrm{ml}$ of Müeller-Hinton broth in order to obtain a concentration of $1.5 \times 10^{8}$ CFU/ml (0.5 MacFarland). The inoculum was then diluted to $1.5 \times 10^{2} \mathrm{CFU} / \mathrm{ml}$. One hundred and ninety microliters of this suspension was transferred to each microplate well. Ten microliters of each extract solution was added to the microplate wells and incubated at $35^{\circ} \mathrm{C}$ for 18 to $20 \mathrm{~h}$. Extracts were prepared to 20 times the desired test concentration $(2 \mathrm{mg} / \mathrm{ml})$ in water or $50 \%$ DMSO solution. Results were analyzed visually and classified according to the following patterns: $+=$ bacterium colonies deposited in the bottom of the well, $++=$ turbidity with bacterium colonies being deposited, $+++=$ light turbidity, and $++++=$ total growth inhibition.

The extracts were screened at a concentration of $100 \mu \mathrm{g} / \mathrm{ml}$. Extracts that showed inhibitory activity at this concentration were submitted to a subculture of the broth media in Müeller Hinton agar $\left(\mathrm{Oxoid}^{\circledR}\right.$, Basingstoke, Hampshire, England) in order to evaluate bacterial growth (8).

\section{Determination of minimal inhibitory concentration and minimal bactericidal concentration}

Minimal inhibitory concentration (MIC) and minimal bactericidal concentration (MBC) were determined for the extracts that showed total growth inhibition using the protocol described above. Extract concentrations of 10 to $100 \mu \mathrm{g} / \mathrm{ml}$ in steps of $10 \mu \mathrm{g}$ were evaluated. The concentration at which there was no visually detectable bacterial growth was taken as the MIC, and the concentration at which there was no bacterial 
growth after inoculation in Müeller-Hinton $\operatorname{agar}\left(\mathrm{Oxoid}^{\circledR}\right)$ was taken as the MBC.

\section{Results}

Results were visually analyzed and bacterial growth inhibition was confirmed after inoculation in Müeller-Hinton agar. Many extracts showed some degree of inhibition of bacterial growth at concentrations of 100 $\mu \mathrm{g} / \mathrm{ml}$, represented by "++". The MIC and MBC of these extracts are currently being obtained. The families of the plants from which the extracts were obtained, the total number of extracts obtained for the current family, and the number of extracts whose antibacterial activities were classified as "++" against the respective bacteria tested are reported in Table 1.

Table 2 lists the seven extracts tested at the concentration of $100 \mu \mathrm{g} / \mathrm{ml}$ and classified as "+++" against $E$. faecalis. Table 3 lists the three plant extracts that showed antibacterial activity against $S$. aureus and E. faecalis, and their respective MIC and $\mathrm{MBC}$.

Table 1. Antibacterial activity of extracts prepared from plants obtained in the Amazon Rain Forest and the Atlantic Forest.

\begin{tabular}{|c|c|c|c|c|c|}
\hline Family & $\begin{array}{c}\text { No. of extracts } \\
\text { evaluated }\end{array}$ & $\begin{array}{l}\text { No. of extracts } \\
\text { with }++ \text { activity }\end{array}$ & Family & $\begin{array}{c}\text { No. of extracts } \\
\text { evaluated }\end{array}$ & $\begin{array}{l}\text { No. of extracts } \\
\text { with }++ \text { activity }\end{array}$ \\
\hline Anacardiaceae & 1 & 1 Sau; 1 Efae & Melastomataceae & 23 & 13 Sau; 8 Efae \\
\hline Annonaceae & 34 & 28 Sau; 5 Efae & Meliaceae & 9 & 5 Sau; 3 Efae \\
\hline Apocynaceae & 54 & 20 Sau; 6 Efae & Memecilaceae & 4 & 3 Sau; 2 Efae \\
\hline Aquifoliaceae & 3 & 3 Sau; 2 Efae & Monimiaceae & 1 & 1 Sau; 1 Efae \\
\hline Balanophoraceae & 1 & 1 Efae & Moraceae & 3 & 3 Sau; \\
\hline Bignoniaceae & 16 & 10 Sau; 1 Efae & Myristicaceae & 6 & 6 Sau; 2 Efae \\
\hline Bombacaceae & 2 & 2 Sau; 2 Efae & Myrsinaceae & 6 & 6 Sau; 3 Efae \\
\hline Boraginaceae & 5 & 4 Sau; 1 Psa & Myrtaceae & 17 & 17 Sau; 11 Efae \\
\hline Burseraceae & 10 & 6 Sau; 1 Efae & Ochnaceae & 3 & 2 Sau; 2 Efae \\
\hline Capparidaceae & 8 & $2 \mathrm{Sau}$ & Olacaceae & 6 & 5 Sau; 3 Efae \\
\hline Caryocaraceae & 5 & 4 Sau; 3 Efae & Orchidaceae & 1 & $1 \mathrm{Sau}$ \\
\hline Chrysobalanaceae & 15 & 12 Sau; 1 Efae & Passifloraceae & 1 & $1 \mathrm{Sau}$ \\
\hline Clusiaceae & 43 & 34 Sau; 18 Efae; 1 Ecol & Polygalaceae & 1 & $1 \mathrm{Sau}$ \\
\hline Combretaceae & 8 & 8 Sau; 5 Efae & Polygonaceae & 14 & 11 Sau; 5 Efae \\
\hline Commelinaceae & 1 & $1 \mathrm{Sau}$ & Proteaceae & 2 & 2 Efae \\
\hline Connaraceae & 10 & 9 Sau; 4 Efae & Rabdodendraceae & 7 & 4 Sau; 2 Efae \\
\hline Convolvulaceae & 1 & $1 \mathrm{Sau}$ & Rhyzophoraceae & 3 & 2 Sau; 2 Efae \\
\hline Dilleniaceae & 4 & 3 Sau; 2 Efae & Rubiaceae & 51 & $35 \mathrm{Sau} ; 10$ Efae \\
\hline Ebenaceae & 5 & 4 Sau; 2 Efae & Rutaceae & 4 & 4 Sau; 2 Efae \\
\hline Erythroxylaceae & 2 & $1 \mathrm{Sau}$ & Sapindaceae & 12 & 7 Sau; 5 Efae \\
\hline Euphorbiaceae & 33 & $21 \mathrm{Sau} ; 14$ Efae & Sapotaceae & 4 & 4 Sau; 1 Efae \\
\hline Flacourtiaceae & 18 & $15 \mathrm{Sau} ; 6$ Efae & Simaroubaceae & 9 & 6 Sau; 3 Efae \\
\hline Gentianaceae & 5 & $2 \mathrm{Sau}$ & Smilacaceae & 5 & 4 Sau; 3 Efae; 1 Psa \\
\hline Heliconiaceae & 2 & 2 Sau; 1 Efae & Solanaceae & 2 & $2 \mathrm{Sau}$ \\
\hline Hippocrateaceae & 6 & 5 Sau; 3 Efae & Styracaceae & 2 & 2 Sau; 1 Efae \\
\hline Humiriaceae & 2 & 2 Sau; 2 Efae & Theaceae & 6 & $2 \mathrm{Sau}$ \\
\hline Lacistemataceae & 2 & $1 \mathrm{Sau} ; 1$ Efae & Teophrastraceae & 1 & $1 \mathrm{Sau}$ \\
\hline Lauraceae & 19 & 17 Sau; 6 Efae & Trigoniaceae & 3 & $1 \mathrm{Sau}$ \\
\hline Lecythidaceae & 6 & 6 Sau; 2 Efae & Trimeriaceae & 1 & 1 Sau; 1 Efae \\
\hline Leguminosae & 119 & 95 Sau; 53 Efae & Verbenaceae & 1 & $1 \mathrm{Sau}$ \\
\hline Linaceae & 2 & 2 Efae & Violaceae & 7 & 4 Sau; 4 Efae \\
\hline Loranthaceae & 5 & 5 Sau; 4 Efae & Vochysiaceae & 5 & 4 Sau; 5 Efae \\
\hline Malpighiaceae & 21 & 17 Sau; 11 Efae & & & \\
\hline
\end{tabular}

Activity was measured by the microdilution broth assay at $100 \mu \mathrm{g} / \mathrm{ml}$. "++" indicates that the extracts caused turbidity without culture flocks and that they will be evaluated at higher concentrations. Ecol = Escherichia coli ATCC 25922; Efae = Enterococcus faecalis ATCC 29212; Psa = Pseudomonas aeruginosa ATCC 27853; Sau = Staphylococcus aureus ATCC 29213. 


\section{Discussion}

Plant extracts have been studied against bacteria for years, but in a more intensified way in the last three decades. During this period, a lot of antimicrobial screening evaluations have been published based on the traditional use of Chinese, African, and Asian plant drugs (9-15). During the late 1990's, a large number of manuscripts describing methodologies of screening took part and resulted in more than 30 articles representing antibacterial extracts obtained from Asian and African native plants, but only a few studies relating antibacterial activity of Brazilian plant extracts were found (16-21). Brazil is home to more than $20 \%$ of the world's biodiversity (1) and only a few species have been submitted to any sort of large-scale biological screening. We collected a substantial

Table 2. Antibacterial activity against Enterococcus faecalis of extracts prepared from plants obtained in the Amazon Rain Forest and the Atlantic Forest.

\begin{tabular}{|c|c|c|}
\hline Family & $\begin{array}{c}\text { Number of extracts } \\
\text { evaluated }\end{array}$ & $\begin{array}{c}\text { Number of extracts classified } \\
\text { as +++ against Enterococcus } \\
\text { faecalis ATCC } 29212\end{array}$ \\
\hline
\end{tabular}

\begin{tabular}{lrl}
\hline Asteraceae & 9 & 1 \\
Connaraceae & 10 & 1 \\
Flacourtiaceae & 18 & 1 \\
Lauraceae & 19 & 1 \\
Melastomataceae & 23 & 1 \\
Myrsinaceae & 6 & 1 \\
Rabdodendraceae & 7 & 1 \\
\hline
\end{tabular}

Activity was measured by the microdilution broth assay at $100 \mu \mathrm{g} / \mathrm{ml}$. "+++" indicates that the extracts caused light turbidity and that they will be evaluated at higher concentrations. amount of information about the antimicrobial activity of 705 Brazilian plant extracts which have been collected randomly.

In order to establish the extract concentrations to be used during the screening, we observed that extract concentrations spanning from $25 \mu \mathrm{g} / \mathrm{ml} \mathrm{(22)} \mathrm{to} 2 \mathrm{mg} / \mathrm{ml} \mathrm{(23)} \mathrm{or}$ even $40 \mathrm{mg} / \mathrm{ml}$ (18) have been used. We screened the crude extracts using a concentration of $100 \mu \mathrm{g} / \mathrm{ml}$ (24). Such concentration is nowadays considered the proper concentration an antimicrobial extract should present. The dilution test is a very precise technique that permits us to work with such a low concentration.

Only 3 of 705 extracts showed bactericidal activity: extract VO581 against $S$. aureus and MY841 and SM053 against $E$. faecalis, with the subcultures showing no germ growth at concentrations $\geq 160 \mu \mathrm{g} / \mathrm{ml}$. Several crude extracts apparently inhibited bacterial growth but when the bacteria were subcultured in agar there was growth, as shown above. Among them, we are currently determining the MIC and MBC for all 510 crude extracts $(72 \%)$ that showed "++" results against $S$. aureus, for all the 240 crude extracts $(34 \%)$ that showed "++" results against $E$. faecalis, for the 2 extracts $(0.3 \%)$ that showed "++" results against $P$. aeruginosa, for the extract $(0.14 \%)$ that showed the same result against $E$. coli, and for all the 7 extracts that showed "+++" results against E. faecalis.

Extract MY841 (MIC $=30 \mu \mathrm{g} / \mathrm{ml}$; MBC $=50 \mu \mathrm{g} / \mathrm{ml}$ ), obtained from the stem of a

Table 3. Antimicrobial activity of plant extracts from the Amazon Rain Forest that showed strong activity, and their corresponding minimal inhibitory and minimal bactericidal concentrations.

\begin{tabular}{lccccc}
\hline Family & $\begin{array}{c}\text { Number of extracts } \\
\text { evaluated }\end{array}$ & $\begin{array}{c}\text { Extract classified as }++++^{a} \\
\text { against Enterococcus } \\
\text { faecalis ATCC 29212 }\end{array}$ & $\begin{array}{c}\text { Extract classified as }++++^{a} \\
\text { against Staphylococcus } \\
\text { aureus ATCC 29213 }\end{array}$ & $\begin{array}{c}\text { Minimal inhibitory } \\
\text { concentration } \\
(\mu \mathrm{g} / \mathrm{ml})\end{array}$ & $\begin{array}{c}\text { Minimal bactericidal } \\
\text { concentration } \\
(\mu \mathrm{g} / \mathrm{ml})\end{array}$ \\
\hline Myrsinaceae & 6 & MY841 & 0 & 140 & 160 \\
Smilacaceae & 5 & SM053 & 0 & 80 & 30 \\
Vochysiaceae & 5 & 0 & VO581 & 30 & 50 \\
\hline
\end{tabular}

aActivity was measured by the microdilution broth assay. "++++" indicates that the extracts caused total growth inhibition. 
Myrsinaceae plant, showed antibacterial activity against $E$. faecalis, as also did extract $\mathrm{SM} 053(\mathrm{MIC}=80 \mu \mathrm{g} / \mathrm{ml} ; \mathrm{MBC}=90 \mu \mathrm{g} / \mathrm{ml})$, obtained from the aerial parts of a Smilacaceae plant. Extract VO581 (MIC = $140 \mu \mathrm{g} / \mathrm{ml} ; \mathrm{MBC}=160 \mu \mathrm{g} / \mathrm{ml}$ ), obtained from the stem of a Vochysiaceae plant, showed activity against $S$. aureus. The three active extracts are going to be bioguide fractionated in order to identify their active substances as well as the remaining extracts, whose MICs were $\leq 500 \mu \mathrm{g} / \mathrm{ml}$. Vochysiaceae species have been studied phytochemically and biologically, and beta-sitosterol, betulinic acid and sericic acid have been isolated from their stem bark extracts (25). These substances have shown antibacterial activity against $S$. aureus. Polysaccharides were also isolated from the cell walls of 57 species of this family (26). Myrsinaceae have been found to contain saponins (27), terpenoids (28), and benzoquinone derivatives $(29,30)$, whereas no phytochemical or biological ac- tivity has been reported for Smilacaceae.

It is a matter of major national interest to study the potential of Brazilian forests in offering new lead antibacterial compounds that can be further synthesized and have their activity improved. Thus, we strongly hope to contribute to the conservation and protection of the biodiversity of our forests and to the development of the Brazilian community as a whole.

\section{Acknowledgments}

The authors would like to thank the technicians Mr. Luis Fernandes Coelho, Sergio Alexandre Frana, Daniela Câmara Nepomuceno from UNIP, the graduate students Andréa dos Santos Pereira and Fabíola Lorenze Dergovics from UNIFESP, for technical help, and Prof. Wilson R. Malavasi, from UNIP, responsible for the logistics of our expeditions.

\section{References}

1. Wilson EO \& Peter FM (1988). Biodiversity. National Academic Press, Washington, DC, USA.

2. Dossiê Mata Atlântica (2001). Projeto monitoramento participativo da mata Atlântica. Capobianco JPR (Editor), Instituto Socioambiental; Rede de ONGs Mata Atlântica, Sociedade Nordestina de Ecologia. Ipsis Gráfica e Editora, São Paulo, SP, Brazil.

3. Myers N, Mittermeier RA, Mittermeier CG, Fonseca GAB \& Kent J (2000). Biodiversity hotspots for conservation priorities. Nature, 403: 853-858.

4. Cragg GM, Newman DJ \& Snader KM (1997). Natural products in drug discovery and development. Journal of Natural Products, 60: 52-60.

5. Duke JA \& Vasquez R (1994). Amazonian Ethnobotanical Dictionary. CRC Press, Boca Raton, FL, USA.

6. Cronquist A (1988). The Evolution and Classification of Flowering Plants. 2nd edn. The New York Botanical Garden Press, New York.

7. Younes RN, Varella D \& Suffredini IB (2000). Extração e rastreamento de novas drogas em plantas brasileiras. Acta Oncológica Brasileira, 20: 15-19.

8. Fakeye TO, Itiola OA \& Odelola HA (2000). Evaluation of the antimicrobial property of the stem bark of Picralima nitida (Apocynaceae). Phytotherapy Research, 14: 368-370.

9. Nishibe S, Okabe K, Tsukamoto H, Sakushima A, Hisada S, Baba H \& Akisada T (1982). Studies on the Chinese crude drug "Forsythiae fructus". VI. The structure and antibacterial activity of suspensaside isolated from Forsythia suspensa. Chemical and Pharmaceutical
Bulletin, 30: 4548-4553.

10. Vlietinck AJ, Van Hoof L, Totte J, Lasure A, Vanden Berghe D, Rwangabo PC \& Mvukiyumwami J (1995). Screening of hundred Rwandese medicinal plants for antimicrobial and antiviral properties. Journal of Ethnopharmacology, 46: 31-47.

11. Perez C \& Anesini C (1994). In vitro antibacterial activity of Argentine folk medicinal plants against Salmonella typhi. Journal of Ethnopharmacology, 44: 41-46.

12. Macfoy CA \& Cline El (1990). In vitro antibacterial activities of three plants used in traditional medicine in Sierra Leone. Journal of Ethnopharmacology, 28: 323-327.

13. Maikere-Faniyo R, Van Puyvelde L, Mutwewingabo A \& Habiyaremye FX (1989). Study of Rwandese medicinal plants used in the treatment of diarrhoea I. Journal of Ethnopharmacology, 26: 101109.

14. Forestieri AM, Pizzimenti FC, Monforte MT \& Bisignano G (1988). Antibacterial activity of some African medicinal plants. Pharmacological Research Communications, 20 (Suppl 5): 33-36.

15. Moskalenko AS (1986). Preliminary screening of far-eastern ethnomedicinal plants for antibacterial activity. Journal of Ethnopharmacology, 15: 231-259.

16. Biavatti MW, Vieira PC, da Silva MFG, Fernandes JB, Albuquerque S, Magalhaes CM \& Pagnocca FC (2001). Chemistry and bioactivity of Raulinoa echinata Cowan, an endemic Brazilian Rutaceae species. Phytomedicine, 8: 121-124.

17. Alves TM, Silva AF, Brandao M, Grandi TS, Smania E, Smania Junior 
A \& Zani CL (2000). Biological screening of Brazilian medicinal plants. Memórias do Instituto Oswaldo Cruz, 95: 367-373.

18. Gnan SO \& Demello MT (1999). Inhibition of Staphylococcus aureus by aqueous goiaba extracts. Journal of Ethnopharmacology, 68: 103-108.

19. Nakamura CV, Ueda-Nakamura $T$, Bando E, Melo AF, Cortez DA \& Dias Filho BP (1999). Antibacterial activity of Ocimum gratissimum L. essential oil. Memórias do Instituto Oswaldo Cruz, 94: 675-678.

20. Varanda EA, Raddi MS, Dias FD, Araujo MC, Gibran SC, Takahashi CS \& Vilegas W (1997). Mutagenic and cytotoxic activity of an isocoumarin (Paepalantine) isolated from Paepalanthus vellozioides. Teratogenesis, Carcinogenesis and Mutagenesis, 17: 85-95.

21. Lopes JL (1991). Sesquiterpene lactones from Vernonia. Memórias do Instituto Oswaldo Cruz, 86 (Suppl 2): 227-230.

22. Eloff JN (1998). A sensitive and quick microplate method to determine the minimal inhibitory concentration of plant extracts for bacteria. Planta Medica, 64: 711-713.

23. Loganga Otshudi A, Foriers A, Vercruysse A, van Zeebroeck A \& Lauwers S (2000). In vitro antimicrobial activity of six medicinal plants traditionally used for the treatment of dysentery and diarrhoea in Democratic Republic of Congo (DRC). Phytomedicine, 7: 167-172.

24. Suffredini IB, Bacchi EM, Sakuda TMK, Ohara MT, Younes RN \& Varella AD (2002). Antibacterial activity of Apocynaceae extracts and MIC of Tabernaemontana angulata stem organic extract. Revista Brasileira de Ciências Farmacêuticas, 38: 89-94.

25. Hess SC, Brum RL, Honda NK, Cruz AB, Moretto E, Cruz RB, Messana I, Ferrari F, Cechinel Filho V \& Yunes RA (1995). Antibacterial activity and phytochemical analysis of Vochysia divergens (Vochysiaceae). Journal of Ethnopharmacology, 47: 97-100.

26. Mayworm MA, Buckeridge MS \& Salatino A (2000). Monomer composition of polysaccharides of seed cell walls and the taxonomy of the Vochysiaceae. Phytochemistry, 55: 581-587.

27. Kim HK, Farnsworth NR, Fong HH, Blomster RN \& Persinos GJ (1970). Biological and phytochemical evaluation of plants. VII. Isolation and identification of a tumor inhibitor from Wallenia yunquensis (Myrsinaceae) as Mysine-saponin. Lloydia, 33: 30-35.

28. De Tommasi N, Piacente S, De Simone F, Pizza C \& Zhou ZL (1993). Characterization of three new triterpenoid saponins from Ardisia japonica. Journal of Natural Products, 56: 1669-1675.

29. Fukuyama Y, Kiriyama Y, Kodama M, Iwaki H, Hosozawa S, Aki S \& Matsui K (1995). Naturally occurring 5-lipoxygenase inhibitors. VI. Structures of ardisiaquinones D, E, and F from Ardisia sieboldii. Chemical and Pharmaceutical Bulletin, 43: 1391-1394.

30. Abourashed EA, El-Feraly FS \& Hufford CD (1999). Carboxylic acid microbial metabolites of the natural benzoquinone, maesanin. Journal of Natutal Products, 62: 714-716. 